\title{
PERENCANAAN STRATEGI HUMAS PEMPROV BANTEN PASCA DITETAPKANNYA KEK PARIWISATA TANJUNG LESUNG, PANDEGLANG, BANTEN
}

\author{
Iman Mukhroman, Rangga Galura Gumelar \\ Program Studi Ilmu Komunikasi, Universitas Sultan Ageng Tirtayasa (UNTIRTA)
}

\begin{abstract}
ABSTRAK
Keputusan pemerintah dalam PP.No.26/2012 yang menetapkan wilayah Tanjung Lesung Pandeglang Banten sebagai Kawasan Ekonomi Khusus (KEK) Pariwisata harus menjadi prioritas bersama. Dalam konteks ini kepentingan Nasional tentunya membawa perubahan dan signifikansi kepada daerah baik dalam bidang ekonomi dan budaya. Penelitian ini bertujuan mengetahui bagaimana sesungguhnya perencanaan strategi Humas Pemprov Banten pasca ditetapkannya PP tersebut dengan fokus pada model perencanaan strategi Public Relations dari Ronald D. Smith yang terdiri atas empat fase yang dimulai dengan fase Formative Research, Strategy, Tactics dan Evaluative Research. Pada setiap fase tersebut terdapat tahapan-tahapan perencanaan PR yang mana pada setiap tahapan tersebut dilakukan analisis dengan menggunakan observasi, studi dokumentasi dan wawancara mendalam sebagai tehnik pengambilan data. Hasil pengolahan data memberikan jawaban bagaimana sesungguhnya peran dari Humas Pemprov Banten sangat kecil dan tidak banyak memiliki kontribusi dalam pelaksanaan KEK ini. Hal ini terjadi karena definisi dan perspektif Humas itu sendiri tidak sama dengan fungsi Humas yang telah kita kenal dalam dunia kerja. Peran Humas Pemprov Banten hanya sebagai pencatat seremonial dan penghubung media tanpa ada suatu kewenangan yang besar dalam menysusun dan mengembangkan pesan. Hasil penelitian ini menunjukkan bahwa Humas Pemprov Banten dalam menyelenggarakan dan mengaplikasikan PP tersebut kurang maksimal. Oleh karenanya harus ada terobosan dan perubahan paradigma tentang fungsi dan peran Humas itu sendiri di lingkungan Pemprov Banten
\end{abstract}

Kata-kata kunci: Perencanaan, Strategi, Humas Pemprov Banten, Kawasan Ekonomi Khusus, Pariwisata, Tanjung Lesung.

\section{PUBLIC RELATIONS STRATEGY PLANNING OF BANTEN PROVINCIAL GOVERNMENT AFTER THE ESTABLISHMENT OF TANJUNG LESUNG TOURISM SPECIAL ECONOMIC ZONES}

\begin{abstract}
In Government decree No.26/20012 which declares Tanjung Lesung Pandeglang Banten as the Special Economic Zones of Tourism. Tourism should be an important and priority issue not only for the central government but also for local government because its significance effects not only in economic but also culture, tourism etc. This research aim is to know how the PR strategic of Government Banten after the declared Government's decree, which is focused on model of Public Relations Planning Srategy from Ronald D. Smith. The model has divided into four phases: Formative Research, Strategy, Tactics and Evaluative Research. Each phase has public relations planning stage applying analizes of bservation, documentation studies and in-depth interviews as a data collection technique. Research shows that the role of Public Relations Banten Government is very little and not contributed much for this research. Government of Banten used the PR only to make documentation of ceremonial events or just the facilitator with the local media is the cause of the little contribution. They don't have the authority to create and developed the message. The result of research shows that PR of Government's Banten in applying the Government Rule (PP) has not reach its maximum potential. Therefore there must be a breakthrough on paradigm the function and role of public relations itself in Banten Government Province.
\end{abstract}

Keywords: Planning, Strategy, Public Relations of Government Banten, The Special Economic of Tourism, Tanjung Lesung.

Korespondensi: Iman Mukhroman, S.Sos., M.Si. Program Studi Ilmu Komunikasi, Universitas Sultan Ageng Tirtayasa (UNTIRTA), Jl.Raya Jakarta Km. 4, Pakupatan, Serang, Banten. Email: iman_mukhroman@yahoo.com 


\section{PENDAHULUAN}

Kawasan Tanjung Lesung di sebelah barat Pulau Jawa tepatnya di Kecamatan Panimbang, Kabupaten Pandeglang, Provinsi Banten selama ini dikenal dengan daerah wisata pantai yang indah dan bisa ditempuh melalui jalur darat kurang lebih 3.5 jam dari Jakarta, Ibu Kota Negara, yang karena letaknya yang strategis dengan pusat pemerintahan, memungkinkan kawasan strategis ini bisa berkembang menjadi daerah tujuan wisata ataupun destinasi wistaa unggulan selain Bali.

Saat ini, sektor pariwisata diyakini masih menjadi salah satu sektor unggulan sebagai sumber devisa bagi Negara. Menurut catatan BPS Propinsi Banten, aktivitas kepariwisataan di Propinsi Banten telah memberikan tambahan bruto sebesar Rp. 6.04 Triliun. Angkutan pariwisata dan restoran tercatat sebagai penyumbang terbesar yang disusul perhotelan. Hal ini menunjukkan bahwa sektor pariwisata di Banten, termasuk pariwisata Tanjung Lesung sangat potensial dalam memberikan masukan pendapatan daerah.

Menurut Dirjen Pengembangan Destinasi Pariwisata Firmanysah Rahim, dengan adanya Kawasan Ekonomi Khusus Tanjung Lesung diharapkan akan tumbuh 7 Kawasan lainnya seluas 2.500 Ha termasuk Tanjung Lesung Water Front City mencapai 170.000 wisatawan dengan tingkat hunian $50 \%$ atau 31 juta wisatawan pertahun. Dan juga diharapkan dapat menyerap 85.000 tenaga kerja dan dapat menumbuhkan sektor-sektor industri penunjang operasional insdustri pariwisata, kegiatan ekonomi lainnya dan pemukiman (Pandeglang, 2012).

Ditetapkannya Peraturan Pemerintah (PP) No. 26 Tahun 2012 tanggal 26 Februari 2012 mengenai Kawasan Ekonomi Khusus (KEK) Tanjung Lesung, tentunya menjadi suatu kepercayaan dari pemerintah pusat yang melihat potensi wisata Tanjung lesung bisa berkotribusi bagi pembangunan ekonomi nasional. Dalam PP Nomor 26 Tahun 2012, kawasan ekonomi khusus (KEK) Tanjung lesung dengan luas wilayah mencapai 1.500 Ha ini masuk pada Kawasan Ekonomi Khusus Zona Pariwisata. Sejalan dengan hal ini, tentunya pemerintah Provinsi dengan kabupaten/kota terkait harus bekerja keras melakukan konsolidasi dan sinkronisasi dalam menjalankan amanat PP tersebut. Koordinasi dan sinkronisasi ini penting dalam hal pengendalian pembangunan di Provinsi Banten.

Konsekuensi logis dari ditetapkannya Tanjung Lesung sebagai KEK Pariwisata, tentunya harus berdasar pada rencana Pembangunan Jangka Menengah Daerah (RPJMD) Provinsi Banten 2012-2017 yang dijabarkan pada rencana kerja pemerintah daerah Provinsi Banten yang mendukung kebijakan strategis nasional tersebut dengan menciptakan iklim investasi yang kondusif melalui pembangunan infrastruktur yang memadai, mengingat selama ini infrastruktur jalan yang kurang baik menjadi kendala kurang maksimalnya kunjungan wisatawan ke Banten, termasuk juga ke Tanjung Lesung, selain tentunya akan menimbulkan dampak multiplier bagi daerah tersebut.

Hadirnya 26 Hotel, resort dan kondominium dengan fasilitasnya ternyata tidak lantas membuat banjirnya wisatawan untuk datang ke wilayah ini. Tercatat target yang ditetapkan pada tahun 2012 jumlah wisatawan baik lokal ataupun asing 2,5 juta orang, pada tahun 2013 jumlah pengunjung yang ditargetkan mencapai 4 juta (Bappeda Pandeglang, 2012). Sesungguhnya hal ini tidaklah realitas, dikarenakan Bali saja menargetkan pada tahun 2013 hanya 3,1 juta wisatawan. Infrastruktur yang buruk kemudian menjadikan alasan banyaknya wisatawan yang urung datang. Banyak yang mengeluhkan karena akses yang sulit dan ketidaknyamanan terhadap infrastruktur yang ada (Kompas, 2013).

Provinsi Banten sebagai salah satu daerah penyangga antara pulau Jawa dan Sumatera dalam strategi MP3EI 2011-2025 tentunya memiliki peran strategis seiring dengan terbitnya Peraturan Pemerintah (PP) No. 26 tahun 2012. Untuk bisa menjabarkan dan menterjemahkan kebijakan pemerintah Provinsi Banten yang sudah memasukan pembangunan Kawasan Ekonomi Khusus (KEK) Tanjung Lesung pada RPJMD Provinsi Banten tahun 2012-2017, dalam rencana pemerintah daerah, utamanya dalam menghadapi dampak multiplier, keberadaan humas pemerintah Provinsi Banten menjadi penting artinya dalam membuat suatu perencanaan strategi kehumasan dalam hal pengembangan KEK Pariwisata Tanjung Lesung. Humas bukan saja sekedar berada pada wilayah "seremoni" semata, tetapi peran humas haruslah mejadi lebih besar, termasuk men- 
jawab tantangan dan persoalan terkait dengan sikap maupun kepentingan publik terkait. Hal ini selaras dengan pengertian Public Relations:

PR adalah fungsi manajemen yang mengevaluasi sikap publik, mengidentifikikasi kebijaksanaan-kebijaksanaan dan prosedur-prosedur seorang individu atau sebuah organisasi berdasarkan kepentingan publik, dan menjalankan suatu program untuk mendapatkan pengertian dan penerimaan dari masyarakat (PR News, dalam Moore HF, 2004)

Berdasar definisi tersebut, bisa dikatakan bahwa humas adalah kegiatan komunikasi yang terencana, terorganisir dan berkelanjutan antara organisasi dan publik sasaran, yang memiliki esensi fungsi humas untuk mengantisipasi sikap publik, melaksanakan fungsi radar dan control sosial secara berkelanjutan, dan melaksanakan kegiatan terencana untuk mendapatkan pengertian dan pemahaman publik terhadap suatu peristiwa atau kebijakan organisasi yang memiliki dampak terhadap organisasi.

Keberadaan Biro Humas Pemprov Banten idealnya didorong membuat perencanaan dan mengadakan aktivitas-aktivitas yang mampu membangun sinergisitas dengan publik atau stakeholder yang memiliki keleluasaan akses mengikuti setiap perkembangan internal baik yang formal maupun informal sekaligus menjadi tulang punggung pemasok utama informasi dalam pengambilan keputusan. Salah satunya dalam membuat rumusan rencana strategi humas Pemprov Banten dalam hal pengembangan KEK Pariwisata Tanjung Lesung, Pandeglang, Banten, sebagaimana yang kemudian juga menjadi concern peneliti.

Dalam penelitian ini, kami mengguanakan model perencanan strategi public relations dari Ronald D. Smith. Dalam Smith (2005:10) dinyatakan terdapat 4 (empat) fase, dan sembilan tahap dalam kegiatan perencanaan strategi PR (humas), yakni:

Phase One; Formative Research (Riset formatif),

Step 1: Analyzing the situation

Step 2 : Analyzing the organizations

Step 3 : Analyzing the publics

Phase Two: Strategy
Step 4 : Establshing goals and objectives

Step 5 : Formulating Action and Response Strategies

Step 6 : Using Effective Communications

Phase Three: Tactics

Step 7 : Choosing Communication Tactics

Step 8 : Implementing the Straetgic Plan

Phase Four " Evaluative Research

Step 9 : Evaluating the Strategic Plan

Keempat fase tersebut menegaskan bahwa dalam hal perencanaan kegiatan humas Pemprov Banten dalam pengembangan KEK Pariwisata Tanjung Lesung haruslah dimulai oleh riset dan diakhiri pula oleh riset. Karenanya, yang menjadi jantung dari semua kegiatan humas adalah perencanaan yang efektif dan kreatif.

Berdasarkan pada model perencanan strategi public relations dari Ronald D. Smith sebagaimana tersebut pada pendahuluan, rumusan masalah penelitiannya adalah Bagaimana Perencanaan Strategi Humas Pemprov Banten pasca Ditetapkannya KEK Pariwisata Tanjung Lesung, Pandeglang, Banten?. Hal ini kemudian dinyatakan pada pernyataan permasalahan yaitu bagaimana perencanaan strategi Humas dalam melakukan riset formatif dalam hal pengembangan KEK Pariwisata Tanjung Lesung, Pandeglang, Banten?, bagaimana perencanaan strategi Humas dalam melakukan strategi dalam hal pengembangan KEK Pariwisata Tanjung Lesung, Pandeglang, Banten?, bagaimana perencanaan strategi Humas dalam melakukan taktik-taktik dalam hal pengembangan KEK Pariwisata Tanjung Lesung, Pandeglang, Banten? dan bagaimana perencanaan strategi Humas dalam melakukan riset evaluatif dalam hal pengembangan KEK Pariwisata Tanjung Lesung, Pandeglang, Banten?

\section{METODE PENELITIAN}

Penelitian ini menggunakan metode kualitatif yakni pendekatan yang berawal pada data dan bermuara pada kesimpulan (Bungin, 200: 18). Hal ini senada dengan yang dinyantakan Kiryantono (2006) bahwa pendekatan kualitatif bertujuan untuk menjelaskan fenomena dengan sedalam-dalamnya melalui pengumpulan data sedalam-dalamnya dengan lebih ditekankan pada persoalan kedalaman (kualitas) data bukan banyaknya (kuantitas) data. 
Jenis penelitian ini adalah penelitian deskriptif, yakni penelitian yang menggambarkan, meringkas berbagai kondisi, berbagai situasi atau variabel yang timbul dimasyarakat yang menjadi objek penelitian. Kemudian menarik kepermukaan sebagai suatu ciri atau gambaran tentang kondisi, situasi ataupun variabel tertentu (Bungin, 2001).

Paradigma penelitian ini adalah post-positivisme, karena penelitian ini hanya bertujuan mendeskripsikan realita yang ada yaitu perencanaan strategi Humas yang bagaimana dikembangkan oleh Humas Pemprov Banten terkait ditetapkannya KEK Pariwisata Tanjung Lesung, Banten.

Teknik pengumpulan data yang digunakan dalam penelitian ini adalah: (1) Wawancara; (2) Studi dokumentasi; dan (3) Observasi. Sumber data yang diperlukan dalam penelitian ini terbagi atas data primer dan data sekunder. Data primer diambil langsung dari informan/ subyek penelitian.

Dalam hal ini data primer di ambil melalui wawancara (interview). Sedangkan data sekunder adalah data yang tidak langsung berasal dari informan. Oleh karena itu dalam pe- nelitian ini, data sekunder diperoleh melalui data-data dan dokumen-dokumen yang relevan dengan masalah yang diteliti. Data-data tersebut merupakan data yang diperlukan dalam menyelesaikan masalah yang dibahas dalam penelitian ini.

Dalam penelitian ini, data tersebut diperoleh dari para informan, dimana informan ini dipilih secara purposif. Informan dalam penelitian ini terdiri dari informan pangkal dan informan pokok (key informant). Informan penelitian adalah orang yang dimanfaatkan untuk memberikan informasi tentang situasi dan kondisi latar belakang penelitian (Moleong, 2000: 97). Informan merupakan orang yang benar-benar mengetahui permasalahan yang akan diteliti. Dari hasil observasi yang dilakukan, kemudian dipastikan beberapa orang yang akan dijadikan informan, yakni: (1) Kepala Biro/ yang diwakilkan Humas Pemprov Banten; (2) Wakil dari Pemerintah Kabupaten Pandeglang.

Alur pelaksanaan penelitian ini dilakukan sebagaimana bagan berikut:

\section{HASIL DAN PEMBAHASAN}

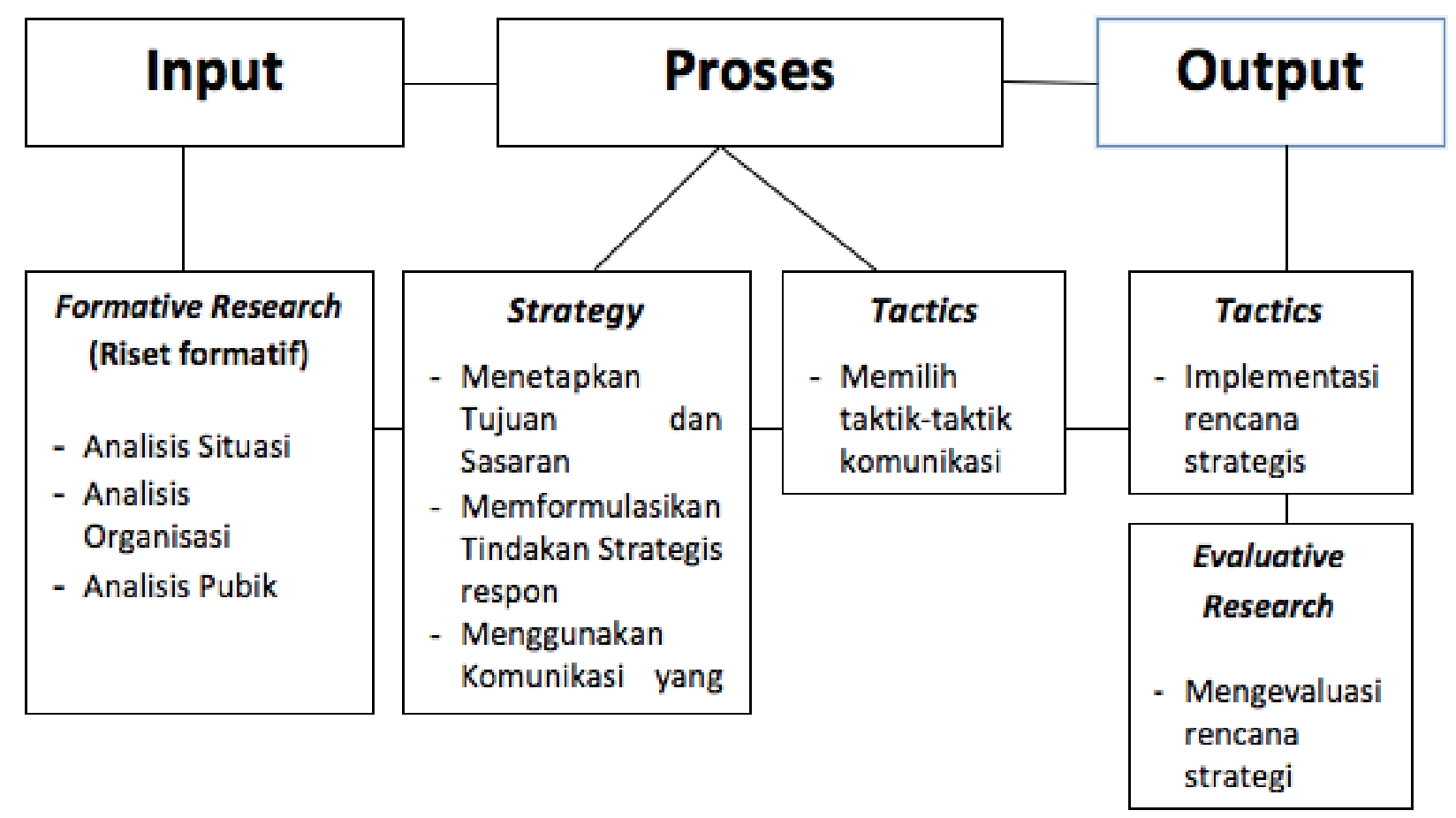


Data hasil penelitian diperoleh dari wawancara, baik itu wawancara terstruktur maupun wawancara tidak terstruktur. Kedua perwakilan ini yang kami anggap layak sebagai narasumber, karena kompetensi dan wawasannya terhadap permasalahan yang hendak diteliti. Adapun kedua perwakilan tersebut adalah:

\begin{tabular}{ccc}
\hline No & N a m a & Instansi \\
\hline \multirow{2}{*}{1} & Ibu Y. Rehan & Kasi Informasi Biro \\
& Faradisa & Humas Pemerintah \\
& & Provinsi Banten \\
& & \\
& & Ketua Tim Persiapan \\
& Ir. Tri Waskito, MM & Pembangunan \\
& & Kawasan KEK \\
& & Tanjung Lesung \\
& & \\
& & \\
& & \\
& &
\end{tabular}

Fokus peneliti dalam menggali informasi terhadap key Informan ini adalah untuk mendapatkan gambaran tentang peran Humas Pemprov Banten sendiri, sebagaimana dalam oleh Cutlip bahwasannya peran PR sangatlah penting dan bagi kelancaran ataupun keberhasilan organisasi tersebut. Adapun bahwa kenyataan suatu organisasi tersebut tidak menggunakan peran Humas secara maksimal dimana sesungguhnya dalam prespektif penelitian posisi Humas ini menjadi Biro tersendiri, sehingga sesungguhnya Humas ini memiliki peran yang sangat besar, tetapi peran ini dirasakan tidak maksimal dan sangat disayangkan, seperti yang dikemukakan oleh Ibu Rehan:

.....Humas Pemprov Banten, sesungguhnya tidak bekerja dalam cakupan yang luas, artinya kami disini lebih kepada mencoba membuat berita-berita tentang kegiatan-kegiatan yang dilakukan atau yang ada kaitannya dengan pemerintahan provinsi Banten. Kami bekerjasama dengan para wartawan lokal khususnya untuk memberikan informasi yang sifatnya penting untuk diketahui. Biro Humas ini tidaklah besar atau diisi dengan banyak personil, tetapi kami memang tidak masuk atau tidak dalam kapasitas besar terutama dalam hal seperti strategi kehumasan, karena kami sifatnya hanya dalam batas publikasi.

Pernyataaan tersebut memberikan atau mendudukan kita bahwa definisi Humas yang ada pada teori ataupun bagaimana banyak teori dalam buku yang menyatakan bahwa peran PR adalah sangat strategis tidak dapat kita masukan kedalam pemahaman definisi Humas pemerintahan.

......untuk kasus-kasus seperti halnya pemberitaan yang spesifik seperti tentang adanya berita tentang KEK (Kawasan Ekonomi Khusus) yaitu Tanjung Lesung, sesungguhnya jika ada pemberitaan atau pertanyaan yang sifatnya teknis maka kita akan berikan langsung kepada Dinas yang terkait, seperti Dinas Kominfo ataupun Disbudpar. Sehingga ada dua kemungkinan yang terjadi yang pertama adalah dinas terkait akan langsung menanggapinya atau kemudian mereka akan memberikan tanggapannya kepada kami dan kami akan sampaikan tanggapan tersebut kepada media massa khususnya media lokal .

Lebih lanjut Key Informan ini kemudian menjelaskan bahwa dengan keterbatasan $\mathrm{Hu}$ mas maka ada beberapa langkah yang diambil agar kepentingan Humas ini sendiri dapat bergerak secara maksimal.

.....dengan keterbatasan yang kami miliki saat ini, kami mengupayakan untuk menjaga atau tetap menyaring informasi-informasi yang terkait dengan pemberitaan tentang Pemprov Banten, khususnya yang terkait dengan KEK ini, karena ini sudah merupakan program nasional dan tentunya disorot maka sebagai Humas Banten kami harus memperbaharui dan terus mempromosikannya. Untuk itu kami harus bekerjasama dengan baik dengan pekerja pers lokal, masyarakat dan para akademisi tentang kemungkinan dampak yang akan terjadi dalam program KEK ini, tanggapan ataupun permasalahan yang kami dapatkan kemudian kami sampaikan kepada yang terkait sehingga saat itu maka dapat dikatakan bahwa tugas kami telah selesai menunggu petunjuk ataupun arahan selanjutnya......

.........bukannya kami tidak mengetahui bahwa promosi atau informasi yang diberikan terkait tentang KEK ini tidak terlalu maksimal, ini terkait juga dengan job desk kami yang dilihat secara keseluruhan tidak sama dengan apa yang ada Anda sebagai Akademisi bayangkan. Kami masih dalam 
tataran bagaimana membuat berita untuk menjadikan opini publik ataupun mencoba merespon terkait opini di masyarakat. Tidak jarang kemudian permasalahan muncul, ketika masyarakat kemudian memiliki pandangan dan menuntut bahwa kami sebagai Humas Pemprov Banten tidak berperan secara maksimal. Kasus KEK ini ranahnya bukan sebatas publikasi semata tetapi KEK ini telah menjadi konsumsi nasional dan bahkan telah terjadi politisasi didalamnya. Tentunya dalam suatu program yang digulirkan apalagi ini menyangkut kepada kehidupan masyarakat maka kami harus sangat hati-hati terhadap pemberitaan yang kami buat dank arena tupoksi dalam masalah tersebut adalah dengan dinas terkait, maka kami bukan dalam kapasitas menentukan strategi dalam perancangan program KEK tersebut.

Kenyataan ataupun isi dari wawancara ini terlihat dan dapat kita pahami bahwa sesungguhnya PR ataupun Humas yang ada dalam Pemprov ini masih sangat terbatas dalam ranah hanya pada bidang pemberitaan yang sifatnya hanya pasif tidak dalam kapasitas yang memiliki peran penting dalam melakukan strategi khusus pada program KEK.

Kenyataan ini tentnya memberikan suatu pembukaan paradigma kepada kita bahwasannya pemahaman PR dalam wilayah pemerintah masih bersifat kepada masalah menulis dan memberikan berita saja. Peneliti kemudian mencoba mengembangkan lebih lanjut tentang dimana sesungguhnya peran strategis dari program KEK ini jika memang dirasakan bahwa Humas Pemprov Banten kemudian menyatakan bahwa mereka tidak sepenuhnya memiliki peran yang banyak atau signifikan. Untuk itu, peneliti kemudian memutuskan untuk merujuk pada pernyataan salah satu perwakilan institusi pemerintah Kabupaten Pandeglang terkait dengan permasalahan penelitian ini, yakni Bapak Ir. Tri Waskito, MM selaku Ketua Tim Persiapan Pembangunan Kawasan KEK Tanjung Lesung Pemkab Pandeglang.

Hal ini penting untuk dilakukan dikarenakan program KEK (Kawasan Ekonomi Khusus) yang telah menjadi program ataupun Agenda nasional ini terletak dikawasan pemerintahan Kabupaten Pandeglang. Sebagai tuan rumah tentunya pemerintah Kabupaten Pandeglang dalam hal ini memiliki peran yang sangat penting dan mungkin sebagai ujung tombak dalam pelaksanaan sosialisasi program KEK ini. Bukan tidak mungkin bahwa Pemerintah Pandeglang dalam hal ini harus menjembatani tentang konflik di masyarakat, karena dalam suatu kebijakan tentunya ada pro dan kontra dari masyarakat.

Peneliti mencoba mengkaitkan isi wawancara dengan peran dari pemerintah Kabupaten Pandeglang ini dalam bagian PR. Walaupun institusi ini tidak berada dalam naungan Humas, tetapi key informan ini dianggap layak untuk dijadikan sumber informasi pada penelitian ini. Humas Kabupaten Pandeglang ini sendiri, pada dasarnya merupakan Humas yang hanya sebatas pengumpulan dan pembuatan berita, tetapi hal-hal teknis yang terkait dengan KEK (Kawasan Ekonomi Khusus) kemudian ditangani oleh Dinas Kebudayaan dan Pariwisata Pandeglang yang bekerjasama dengan dinas lainnya di Provinsi. Kawasan KEK ini merupakan suatu terobosan yang sangat penting, tetapi juga merupakan suatu tantangan yang berat, seperti yang disampaikan oleh key informant kami.

......bahwa adanya Tanjung Lesung sebagai Kawasan Ekonomi Khusus yang dicanangkan pemerintah merupakan suatu kebanggaan tentunya. Proses yang dilalui sangatlah panjang. Akan banyak orang kemudian lebih mengenal lagi tentang Banten. Tetapi harus jujur kami akui, dengan adanya KEK ini kami mengharapkan bahwa kami sebagai pemerintah Pandeglang kemudian dikenal kembali di kalangan luas. Saat ini orang memang telah banyak mengenal pantai Carita sebagai tempat wisata, tetapi orang tidak mengetahui bahwa pantai Carita tersebut berada di Kabupaten Pandeglang. Artinya bahwa, disini kami pun ingin agar objek wisata yang kemudian dikenal di masyarakat luas kemudian mengangkat nama daerah kami, dan tentunya ini adalah suatu kesempatan yang besar.

Pemerintah Pandeglang dalam hal ini menyadari bahwasannya ini merupakan sebuah proyek yang besar dan butuh suatu strategi dimana dalam mensosialisaikan dan menjalankan program ini hingga kemudian berhasil. Pada kesempatan Rapat Koordinasi Tim Persiapan dan Penandatangan Rencana Aksi Daerah (RAD) 
Pembangunan Kawasan Ekonomi Pariwisata Tanjung Lesung. Rapat yang bertempat di Op room II Sekretariat Daerah Kabupaten Pandeglang, tanggal 08 Oktober 2012, Ketua Tim Persiapan Pembangunan Kawasan KEK Tanjung Lesung Pemkab Pandeglang, Bapak Ir. Tri Waskito, MM., mengutarakan beberapa point penting terkait dengan progress pengembangan KEK Tanjung Lesung diantaranya sebagai berikut: (1) tindak lanjut penetapan KEK Pariwisata Tanjung Lesung meliputi Pembentukan Kelembagaan, Pelimpahan Kewenangan, Penetapan Badan Usaha Pembangunan KEK, Pembangunan KEK, Insentif dan Kemudahan, Pemantauan dan Evaluasi, Penetapan Badan Usaha Pengelola KEK, Operasional KEK, (2) beberapa tantangan mendasar yang perlu dihadapi antara lain: Orientasi ekonomi sosial budaya lokal yang perlu intens didorong dan dibina agar sinergis dengan sektor pariwisata, Keterbatasan infrastruktur transportasi darat, laut dan udara, Penertiban lahan terlantar pada Kawasan Strategis Pariwisata Pantai Barat Pandeglang khususnya koridor Citeureup, Camara Dan Sumur, (3) beberapa hal yang harus diperhatikan untuk menindaklanjuti penetapan KEK Pariwisata Tanjung Lesung, antara lain: kesiapan aparatur di daerah dalam menyikapi masuknya investasi di daerah, kesiapan perangkat pendukung proses masuknya investasi, dan kesiapan masyarakat yang bermukim di daerah tersebut dengan masuknya kegiatan investasi, (4) untuk mendukung percepatan pembangunan Kawasan Ekonomi Khusus (KEK) Pariwisata Tanjung Lesung, dikeluarkan Keputusan Bupati Nomor: 556/kep.77-huk/2012 tentang Pembentukan Tim Persiapan Pembangunan Kawasan Ekonomi Khusus (KEK) Pariwisata Tanjung Lesung, dan (5) dalam melaksanakan tugasnya, Tim Persiapan dibantu oleh Kelompok Kerja (Pokja) yang terdiri dari Pokja Legislasi yang pada intinya bertugas untuk mempersiapkan segala sesuatu yang berkaitan dengan perangkat hukum dan Pokja Advokasi yang memiliki tugas mempersiapkan masyarakat terutama disekitar kawasan agar siap dalam menghadapi KEK Pariwisata Tanjung Lesung.

Peneliti kemudian mencoba menggali lebih dalam tentang peran dari Pemerintah Kabupaten Pandeglang ini dimana didalamnya terdapat beberapa strategi PR seperti yang dikatakan oleh Ronal D. Smith dimulai dari beberapa fase yaitu: Phase One; Formative Research; Phase Two: Strategy; Phase Three; Tactic; Phase Four; Evaluative Research. Hal ini dikarenakan memang peran dari pemerintah Pandeglang inilah yang sangat besar, termasuk kedalam persiapan dan kesiapan masyarakat pada perencanaan tersebut. Pemerintah lokal akan berhadapan dan berkomunikasi langsung dengan para masyarakat. Hal ini kemudian diperkuat dengan apa yang dijelaskan oleh Key Informan kami, yaitu:

Permasalahan akan selalu timbul dan harus disadari bahwasannya adanya KEK ini tidak terlalu membuat masyarakat Pandeglang menjadi senang. Banyak sekali masyarakat Pandeglang yang tidak mengetahui tentang apa itu KEK, kemudian banyak sekali diskusi dan tidak jarang penolakan-penolakan yang terjadi karena bagi masyarakat Pandeglang sendiri KEK tidak serta merta merubah hidupnya. Tentunya hal ini bukan tanpa alasan, ketika kemudian Carita menjadi tempat tujuan masyarakat harus kita katakan secara jujur tidak membantu banyak masyarakat. Kemudian masyarakat sulit untuk masuk ke pantai karena akses masuknya telah tertutup oleh bangunan hotel, sehingga apa yang terjadi adalah masyarakat kemudian menjadi penonton semata.

.selain dari itu kita harus cermati bahwa masyarakat Pandeglang adalah masyarakat yang dapat dikatakan sebagai masyarakat yang religius, sehingga sangat sensitif terhadap perubahan-perubahan yang dapat terjadi dilapangan. Sangat tidak dipungkiri bahwasannya ketika kemudian Tanjung Lesung itu menjadi daerah Kawasan Ekonomi Khusus tersebut kemudian merubah gaya hidup masyarakat sekitar, karena harus menyesuaikan dengan gaya hidup mereka yang datang. Inilah yang kemudian menjadi suatu gerakan bagaimana mereka dapat saja menjadi sensitif. Oleh sebab itu, maka kami dari pemerintah daerah harus secara arif dan secara cepat melakukan pendekatan kepada mereka, agar kemudian permalasahan ini tidak menjadi suatu permasalahan besar di kemudian hari.

.......Kita melakukan pendekatan den- 
gan mereka dengan melakukan analisis penduduk asli daerah Tanjung Lesung, kemudian melakukan strategi pendekatan dalam melakukan sosialisasi tentang Kawasan Ekonomi Khusus ini baik dalam acara formal maupun acara informal. Hal ini kami lakukan karena kami menyadari bahwasannya mereka bukanlah yang tergabung dalam pola akademisi tetapi mereka berasal dari kalangan dengan tingkat pendidikan dan pengetahuan yang beragam, hal inilah yang kemudian kami coba untuk dijadikan sebagai strategi dalam sosialisasi kepada masyarakat. Kami pun menggandeng para tokoh masyarakat dan aparatur desa, karena bagaimanapun mereka jelas lebih mengerti dan paham tentang karakteristik masyarakat Tanjung Lesung tersebut.

Pendekatan dan strategi yang dilakukan oleh pemerintah Pandeglang dalam program ini tentunya harus melalui suatu jaringan komunikasi yang baik antara institusi baik di pemerintah Pandeglang itu sendiri dan juga dengan institusi lain seperti pemerintah Provinsi dan daerah lainnya. Ini merupakan suatu keharusan karena program KEK yang telah menjadi program nasional itu sendiri harus sesuai dengan master plan yang kemudian telah ditetapkan. Komunikasi antara lembaga atau institusi ini kemudian diyakinkan oleh key informant kami, yaitu:

.....adanya KEK (Kawasan Ekonomi Khusus) Tanjung Lesung ini tentunya harus didukung denga suatu komunikasi yang baik antar lembaga dan institusi lain, sehingga kemudian program ini dapat berjalan dengan baik. Koordinasi dan komunikasi yang kami tempuh ini dilaksanakan agar terjadi suatu keharmonisan dalam bekerja sehingga kami khususnya sebagai pelaksana dilapangan agar mampu dan dapat menjelaskan kepada masyarakat terutama terkait dengan isu-isu yang dianggap penting.

Dukungan yang positif terutama dalam hal pendanaan termasuk salah satu hal penting dimana sangat dibutuhkan oleh pemerintah daerah terutama bagi Kabupaten Pandeglang. artinya bahwa harus ada suatu integrasi program yang jelas dan nyata dari pihak pemerintah pusat dan daerah, jangan sampai pembangunan ini hanya menjadi suatu wacana saja. Pembangunan bandara contohnya adalah salah satu upaya yang nyata dan patut kita dukung, karena memang akan menjadikan para wisatawan lebih mudah untuk mencapai tujuan. Kami tidak memungkiri bahwa memang untuk mencapai ke daerah Tanjung Lesung membutuhkan waktu yang lama, dan kenyamanan di jalan terasa kurang karena memang tidak banyak tempat yang dapat dijadikan sebagai tempat peristirahatan. Selain dari itu memang kondisi jalan yang masih sempit dan masih dalam perbaikan hingga saat ini tidak dipungkiri membuat para wisatawan menjadi sedikit banyaknya kecewa. Keadaan seperti ini seringkali menjadi bahasan kami, baik dengan tingkat daerah ataupun provinsi. Ini kami sampaikan dalam forum resmi agar kemudian dijadikan catatan-catatan agar kemudian dapat ditindaklanjuti. Sesungguhnya masyarakat Pandeglang tidak anti kepada perubahan atau rencana pembangunan yang telah disepakati, tetapi mungkin harus kita pahami bahwasannya masyarakat Pandeglang mendambakan dan rindu akan adanya suatu perubahan yang positif jika memang kemudian Pandeglang menjadi tempat wisata bertaraf internasional. Pandeglang tidak hanya kemudian dikenal dengan aksi teror dan anarkisme agamanya saja. Memang dalam hal ini kematangan dan komunikasi yang baiklah yang kemudian dapat menjadi solusi diantara semua pihak.

Dari hasil wawancara yang kami lakukan maka peneliti mencoba untuk memberikan analisis atau pandangan terhadap data yang diterima, adapun hasil analisis tersebut adalah:

Pertama, perencanaan strategi Humas Pemprov Banten dalam melakukan riset formatif dalam hal pengembangan KEK Pariwisata Tanjung Lesung, Pandeglang, Banten, dimana pihak Humas Pemprov Banten dalam hal ini bekerja hanya berdasarkan atas job desk yang terbatas, sehingga tidak mencapai suatu yang maksimal. Hal ini didasarkan bahwasannya Hu- 
mas Pemprov Banten lebih ditekankan kepada kegiatan yang bersifat seremonial atau rutinitas di lingkungan Pemprov Banten. Dalam Phase One; Formative Research (Riset formatif) dimana terdapat langkah-langkah:

Analyzing the situation atau situasi yang ada dalam organisasi Biro Humas Provinsi Banten memiliki kelemahan dalam hal sempitnya ruang lingkup kerja atau pemahaman ataupun peran yang dimiliki oleh Biro Humas terkait dengan yang biasa mereka kerjakan. Isu-isu yang berkembang tidak secara langsung ditangani oleh Biro Humas tetapi lebih jauh akan dilemparkan kepada dinas yang terkait. Tetapi sisi lain humas Pemprov Banten memiliki kekuatan dalam hal SDM, dimana mereka sesungguhnya telah paham dan mengetahui peran humas yang lingkupnya luas, dan juga selalu update dengan teknologi informasi yang ada.

Analyzing the organizations atau hubungan yang dibangun tercipta dan terjalin dengan baik. Bagaimana komunikasi yang dibangun baik antara antara atasan dan bawahan ataupun teman sejawat sangat baik. Selain dari itu struktur organisasi humas Pemprov Banten ini masih sangat sederhana. Artinya seperti yang telah dijelaskan pada analisis situasi bahwa memang sistem kerja yang ada memang dalam batasan humas yang masih tradisional.

Selain daripada itu memang humas Pemprov Banten ini sendiri belum dalam kapasitas atau belum berhadapan dengan isu-isu strategis seperti pada isu strategis KEK Tanjung Lesung ini sendiri. Isu yang sesungguhnya memiliki nilai yang tinggi dan butuh suatu gerakan atau mungkin perancanaan yang baik dari sisi humas karena sifatnya nasional dan menjadi perhatian banyak orang bukan saja masyarakat ataupun pemerintah pusat tetapi mungkin menjadi perhatian pihak luar karena hal ini terkait ajakan pemerintah untuk mengajak investor untuk membangun dan mengembangkan Tanjung Lesung.

Harus disadari bahwa publik ataupun masyarakat luas tidak fokus ataupun memberikan perhatian besar terhadap isu KEK ini. Publik tidak disadarkan bagaimana sesungguhnya masyarakat atau warga Banten akan mengambil banyak manfaat atau kesempatan besar dengan adanya KEK ini. Suatu terobosan dan keberhasilan besar sesungguhnya ketika Tanjung Lesung ini masuk dalam KEK, hal ini menunju- kan bahwa pemerintah pusat telah melihat ada potensi besar untuk mengembangkan wilayah ini khususnya wilayah Provinsi Banten, walaupun harus kita akui bahwa dalam potensi positif tentunya akan ada potensi negatif.

Humas Pemprov Banten mengakui bahwasannya memang publik lebih banyak mengenal humas dalam hal pemberitaan ataupun acara-acara seremonial ataupun acara formal terkait dengan berita yang diberitakannya pula. Hal ini memang diakui bahwa peran dari sosialisasi Tanjung Lesung ini lebih banyak diambil dinas terkait seperti halnya Bappeda Provinsi ataupun dinas Pariwisata. Walaupun sesungguhnya merunut kepada pendapat Smith, peran dinas adalah peran teknis tetapi penyampaian informasi hingga menanggapi ataupun mensosialisasikan berita tentang isus-isu strategis sesungguhnya lebih baik dilakukan oleh humas. Oleh sebab itu harus ada suatu perubahan besar dalan prespektif dalam tubuh organisasi ini.

Analyzing the publics berdasarkan jawaban dan persepsi yang dilontarkan oleh pegawai humas Pemprov Banten, mereka masih menganggap bahwa publik ataupun masyarakat di Banten masih dalam persepsi yang tidak haus akan informasi. Tetapi kenyataan sesungguhnya adalah bahwa ketika isu ini menjadi isu nasional publik yang melihat adalah publik dalam wilayah yang luas. Publik yang cenderung cerdas dan jangan dilupakan bahwa pandangan publik ini akan mempengaruhi citra kepada pemerintah Provinsi Banten ini sendiri.

Adapun publik dalam persepsi pemerintah lokal kabupaten Pandeglang adalah wilayah publik yang masih sempit karena mereka berhubungan langsung dengan masyarakat setempat. Sehingga ada suatu perbedaan pengertian publik dalam kacamata humas dan dalam kacamata pemerintah lokal dalam hal ini adalah dinas pariwisata Pandeglang. Publik yang mereka kenal atau mereka ajak untuk mensosialisasikan tentang program ini tidaklah terlalu sulit karena mereka memang telah mengenal karakter masyarakat setempat dengan baik. Tetapi harus diberi perhatian khusus bahwasannya mereka bukanlah organisasi humas, mereka akan cenderung menjawab secara langsung apa yang ditanyakan oleh masyarakat. Tetapi seharusnya dan seyogyanya hal ini lebih tepat jika dipegang atau diaksanakan secara serius oleh humas. Tetapi memang permasala- 
han klasik kembali muncul ketika kemudian ternyata humas dalam pemerintahan kabupaten Pandeglang dalam sbuah artinya organisasi yang begitu sangat kecil ruang lingkupnya.

Selain dari itu dari sisi pemerintah Kabupaten Pandeglang itu sendiri dalam kapasitas sebagai pemerintah daerah sebagai penguasa daerah secara tidak sadar telah melakukan langkah-langkah dalam phase pertama ini, karena mereka langsung telah terbiasa berhubungan langsung dengan masyarakat, mengidentifikasi apa permasalahan yang ada serta melihat situasi yang ada, sehingga ini adalah merupakan masukan besar dalam terciptanya kebutuhan dan keselarasan informasi antara pemerintah dan masyarakatnya.

Kedua, perencanaan strategi Humas Pemprov Banten dalam melakukan Strategi dalam hal pengembangan KEK Pariwisata Tanjung Lesung, Pandeglang, Banten, dimana pada konteks strategi, dimana termasuk dalam Phase two: Strategy, analisis dilakukan dalam 3 tahapan, dimana dimulai dari tahapan Establshing goals and objectives, Formulating Action and Response, dan Using Effective Communications Strategies. Berdasarkan data yang ada tidak ada strategi khusus yang dilakukan oleh Pemprov Banten, tetapi memang Humas Pemprov Banten ini tidak dalam keadaan diam atau pasiv selamanya, tetapi juga melakukan suatu gerakan yang postitif seperti mendekati atau saling memahami dan bertukar pikiran dengan para masyarakat, jurnalistik dan pihak yang terkait agar mereka mendapatkan kebutuhan informasi apa yang seyogyanya diperlukan. Ada beberapa langkah yang dalam model perencanaan PR mutlak dilakukan yaitu:

Establishing Goals and objectives, yaitu melihat dari data atau hasil wawancara yang diterima memang terkait dengan isu strategis dan nasional ini yaitu tentang keputusan bahwa Tanjung Lesung masuk dalam kawasan KEK ternyata belum menjadi suatu prioritas ataupun menjadi suatu target utama pada humas Pemprov Banten. Sehingga visi dan misi humas Pemprov Banten dalam hal ini tidak terlihat atau tidak ada suatu tindakan khusus. Mereka tidak memiliki perintah atau tugas secara khusus bagaimana seharusnya mengawal dan mengembangkan isu-isu yang ada menjadi suatu kekuatan yang lebih baik lagi terutama dalam kesuksesan program KEK ini.
Formulating Action and Response Strategies, dimana Pemprov Banten tidak dalam kapasitas luas sebagai jembatan ataupun sebagai corong informasi terhadap pemberitaan yang terkait dengan isu-isu di pemerintahan Provinsi Banten. Inilah yang sesungguhnya diharapkan peran besar dari humas Pemprov Banten itu sendiri. Tidak disalahkan atau memang dibenarkan ketika kemudian humas Pemprov Banten menggandeng dinas teknis terkait terkait isu strategis KEK Tanjung Lesung ini, tetapi sesungguhnya bagaimana kemudian berita ataupun informasi ini keluar sesungguhnya ini merupakan peran humas.

Using effective communication, dimana disadari atau tidak komunikasi merupakan kunci dari tercapainya suatu tujuan. Dalam hal ini komunikasi harus di jalin dengan baik, baik itu dari sender kepada receiver. Humas Pemprov Banten yang dalam hal ini juga dapat dikatakan sebagai sender dan receiver tergantung dari sisi ataupun posisi dia berada. Ketika menjadi sender maka humas Pemprov Banten dituntut agar memberikan informasi yang sesuai dengan kebutuhan masyarakat, memberikan secara utuh pesan-pesan yang disampaikan kepada receiver sehingga tidak terjadi hambatan-hambatan ataupun kesalahank penerimaan informasi.

Kesalahan atau ketidaksempurnaan penerimaan informasi ini akan mengakibatkan feedback yang tidak sesuai dengan yang diharapkan. Contohnya adalah ketika masyarakat tidak mengetahui secara baik apa maksud dan tujuan dari ditetapkan KEK ini dan kemudian masyarakat Pandeglang yang tidak mengetahui tentang hal ini dan membuat suatu asumsi-asumsi yang negatif tanpa ada suatu komunikasi yang baik terlebih dahulu dengan humas Pemprov Banten maka hal ini akan bermasalah.

Memang Pemprov Banten telah melakukan komunikasi efektif dengan menggandeng ataupun memiliki hubungan dengan media massa lokal. Hal ini memang perlu dilakukan dan dapat dikatakan bahwa hubungan dengan media massa adalah suatu keharusan. Informasi yang disampaikan tentunya dapat bergerak dengan cepat dan dengan jangkauan yang luas, tetapi jika kita lihat bahwa suatu berita adalah merupakan suatu hasil konstruksi dari si pembuat berita tentunya hal ini akan harus dijadikan kemudian perhatian khusus apakah kemudian berita yang kemudian muncul sesuai 
dengan apa yang disampaikan. Karena media pada hakikatnya adalah berorientasi kepada nilai keuntungan, artinya apakah kemudian media menempatkan isu ini sebagai isu yang penting untuk kemudian diangkat dan dibahas. Harus jujur kita katakan bahwa media lokal saat ini akan mengangkat hal-hal yang sekiranya menjadi perhatian publik seperti kasus korupsi, ataupun perseteruan dan ketidakprofesionalan dari aparatur pemerintah. Inilah yang kemudian harus dicarikan sebuah alternatif dan tantangan dari humas Pemprov Banten.

Jika dahulu kita mengenal adanya public opinion leader dimana adalah tokoh-tokoh yang memiliki kredibilitas seperti tokoh masyarakat ataupun pejabat daerah seperti kepala desa ataupun camat. Hal ini memang masih dapat dilakukan, tetapi saat ini masyarakat lebih kritis dan mampu menyerap dan memperoleh informasi dari segala lini sehingga yang terjadi adalah bahwa opinion leader saat ini adalah melalui media bukan dari tokoh masyarakat ataupun pemerintah. Dalam hal ini kemampuan mengelola informasi dan kemampuan dalam merespon dan menggunakan alat teknologi informasi yang ada adalah suatu keniscayaan yang tidak dapat ditepiskan. Dinas terkait seperti Bappeda ataupun Depkominfo mungkin tidak akan berpikir atau menganalisis sejauh ini, tetapi humas tentunya telah sampai pada pemikiran yang lebih jauh ditambah dengan latar belakang dan kegiatan sehari-harinya yang bergelut dengan informasi.

Ketiga, perencanaan strategi Humas Pemprov Banten dalam melakukan Taktik-taktik dalam hal pengembangan KEK Pariwisata Tanjung Lesung, Pandeglang, Banten, dimana ini merupakan fase ketiga (Phase Three: Tactics) dalam hal pencanaan PR, dimana pada fase ini terdapat dua langkah untuk dilakukan analisis yaitu mengaanlisis pada Choosing Communication Tactics dan Implementing the strategic plan. Fase ini memang dapat dikatakan sulit ataupun dapat dikatakan mudah, ini terjadi karena pihak pemerintah itu sendiri tidak dalam konteks atau tidak melihat fenomena yang ada di masyarakat tidak dalam tidak menyetujui pembangunan wisata di Tanjung Lesung.

Choosing Communication Tactics, yaitu taktik komunikasi yang digunakan memang masih sangat sederhana karena memang keterbatasan dari peran humas Pemprov Banten itu sendiri.
Tetapi harus dilihat bahwa harus ada terobosan yang dilakukan oleh Pemprov Banten yang memanfaatkan new media seperti jejaring sosial ataupun internet. Bagaimana penggunaan website resmi dari humas Pemprov Banten itu sendiri harus ada dan selalu berkembang dan memberikan informasih kepada masyarakat terkait dengan permasalahan, rencana ataupun penyampaian informasi penting lainnya. Kecepatan dari internet ataupun new media ini tidak dapat disangsikan dan melalui new media secara cepat pula kita dapat melihat respon yang ditunjukan oleh masyarakat.

Implementing the strategic plan, dimana kegiatan kampanye atau sosialisasi penting dilakukan tetapi bagaimana jenisnya inilah tugas dari humas, bukan hanya sekadar menghamburkan anggaran semata tanpa adanya keefektivan dari segmentasi yang ingin dicapai.

Keempat, perencanaan strategi Humas Pemprov Banten dalam melakukan Riset Evaluasi dalam hal pengembangan KEK Pariwisata Tanjung Lesung, Pandeglang, Banten. Disini merupakan fase terakhir yaitu Phase four: Evaluating the strategic plan. Analisis yang dilakukan hanya mengacu pada satu tahap yaitu evaluasi pada rencana strategis. Bahwa harus ada evaluasi bersama, harus ada koordinasi bersama antara bidang-bidang yang terkait. Humas Pemprov Banten khususnya harus selalu memantau atau memberikan suatu masukan bahkan memutuskan suatu hal jika memang dirasa apa yang dilakukan oleh pemerintah provinsi ataupun kabupaten dirasa masih kurang cukup dan masih jauh dari keinginan masyarakat pada umumnya. Pemerintah daerah dalam hal ini Pemprov Banten harus secara sadar bagaimana kemudian evaluasi ini sebagai sebuah komunikasi yang saling menguntungkan antar kedua belah pihak, sehingga tujuan dari pemerintah dengan ditunjuknya Tanjung Lesung ini menjadi KEK dapat terlaksana dengan baik.

\section{SIMPULAN}

Pasca ditetapkannya PP. No.26 Tahun 2012, peran Humas Pemprov Banten terasa belum maksimal. Koordinasi atau kerjasama yang dilakukan antara pemerintah provinsi dan daerah dalam hal ini adalah pemerintah Kabupaten Pandeglang lebih banyak melibatkan dalam ranah komunikasi antar bidang yang berkaitan 
dengan teknis semata. Dalam kenyataan ini pula bahwa peneliti memiliki kesimpulan, yaitu:

Pertama, dalam hal perencanaan strategi melakukan riset formatif pengembangan KEK Pariwisata Tanjung Lesung, Humas Pemprov Banten belum memahami sepenuhnya bagaimana menggunakan tahapan yang ada pada riset formatif tersebut, sehingga terkesan dalam merespon Tanjung Lesung sebagai KEK Pariwisata dianggap bukan sesuatu yang menjadi mutlak tugas Humas Pemprov Banten, karena terkait juga dengan instansi vertikal lainnya.

Kedua, dalam hal perencanaan strategi melakukan strategi pengembangan KEK Pariwisata Tanjung Lesung, Humas Pemprov Banten belum memiliki strategi yang khusus. Dalam hal ini, Humas Pemrov Banten masih belum memahami apa yang menjadi tujuan dan sasaran KEK dan menganggap kerja-kerja terkait pengembangan KEK dikerjakan oleh tim khusus untuk itu, sehingga terkesan Humas Pemprov Banten tidak melakukan strategi yang pro aktif dan responsif dalam memberikan informasi terkait hal tersebut.

Ketiga, dalam hal perencanaan strategi melakukan taktik-taktik pengembangan KEK Pariwisata Tanjung Lesung, Humas Pemprov Banten belum memahami bagaimana pelaksanaan taktik PR, yang mana dalam menyikapi tentang Tanjung Lesung sebagai kawasan KEK itu bukan menjadi suatu agenda penting dan agenda utama Humas Pemprov Banten, sehingga dengan demikian bahwa hal ini akan menjadi suatu kelemahan dalam mereka bertindak.

Ketiga, dalam hal perencanaan strategi melakukan Riset Evaluasi pengembangan KEK Pariwisata Tanjung Lesung, Humas Pemprov Banten belum bisa melakukan evaluasi yang mendalam. Analisis evaluasi yang dilakukan pada setiap fase berserta tahapan-tahapan rencana strategi Humas Pemprov tersebut menyiratkan kecilnya peranan Humas Pemprov Banten. Perencanaan Humas tidak berjalan dengan semestinya, dikarenakan terminologi akan Humas masih sangat sempit.

Merujuk pada empat simpulan tersebut, kiranya produk penelitian melalui model perencanaan strategi humas Pemprov Banten diharapkan bisa meningkatkan pelaksanaan manajemen perencanaan, pelaksanaan dan pengendalian kegiatan Humas Pemprov Banten dalam pasca ditetapkannya PP. No.26 tahun 2012 tersebut, sehingga keberadaan KEK Pariwisata Tanjung Lesung bisa menghasilkan sisi manfaat yang lebih banyak positifnya bagi masyarakat, dan bisa meminimalisir sisi negatifnya sekaligus bisa menjadi alat kontrol bagi peningkatan kualitas kinerja SKPD terkait dengan pengembangan KEK Pariwisata Tanjung Lesung.

Berdasarkan pada hasil penelitian, maka ada beberap saran yang dapat peneliti rekomendasikan, diantaranya:

Pertama, Humas Pemprov Banten tentunya harus melakukan reorientasi pemahaman dalam melakukan riset formatif dalam hal melakukan analisis situasi, analisis organisasi dan analisis publik.

Kedua, Humas Pemprov Banten harus lebih tanggap dan responsif melakukan aksi dan strategi dalam membangun komunikasi yang sinergis dengan publik terkait pengembangan KEK Tanjung Lesung.

Ketiga, Humas Pemprov Banten harus meningkatkan kemampuan personilnya dalam melakukan taktik komunikasi yang tepat dan efektif dalam pengembangan KEK Tanjung Lesung, sehingga bisa terimplementasi dengan efektif dan efisien.

Keempat, Humas Pemprov Banten harus meningkatkan kemampuan mengevaluasi semua hal terkait tahapan dalam implementasi strategi Humas dalam pengembangan KEK Tanjung Lesung, sehingga bisa menghasilkan output sekaligus input yang bisa menjadi dasar perbaikan terkait hal tersebut.

\section{DAFTAR PUSTAKA}

Bappeda Pandeglang. (2012). Diakses 20 Januari 2013 dari http://bappeda. pandeglangkab.go.id/rapat-koordinasi-tim-persiapan-dan-penandatanganan-rencana-aksi-daerah-rad-pembangunan-kawasan-ekonomi-khusus-kek-pariwisata-tanjung-lesung/

. (2012). Diakses 25 Januari 2013 dari http://bappeda.pandeglangkab. go.id/kek-tanjung-lesung/

BPS Banten. (2010). Banten dalam Angka.

Bungin, B. (2001). Penelitian kualitatif. Jakarta: Kencana Prenada Media. 
Kompas. (2013). Diakses 25 Januari 2013 dari http://properti.kompas.com/ $\mathrm{read} / 2013 / 10 / 19 / 1923209 /$ Infrastruktur.Buruk.Tanjung.Lesung. Bangun. Airstrip.

Moleong, L. (2004). Metodologi penelitian kualitatif edisi revisi. Bandung: Remaja Rosdakarya.

Moore, F. (2004). Humas membangun citra dengan komunikasi. Bandung: Remaja Rosdakarya.

Moore, H. F. (2004). Public relations, principle, cases and problem. Terj. Bandung: Remaja Rosdakarya

Pandeglang. (2012). Diakses 20 Januari 2013 dari http://pandeglang.go.id

Peraturan Pemerintah (PP) No. 26 Tahun 2012

Soemirat, S. \& Ardianto, E. (2003). Dasardasar public relations. Bandung: Remaja Rosdakarya.

Smith, D. R. (2005). Strategic planning for public relations. London: Lawrence Erlbaum. 